\title{
NON-NATIVE ARABIC LANGUAGE TEACHER: LOW TEACHER'S PROFESSIONAL COMPETENCE LOW QUALITY OUTCOMES?
}

\author{
Anwar Sanusi, Sofyan Sauri, Yayan Nurbayan \\ Universitas Pendidikan Indonesia, Bandung, Indonesia \\ Jl. Dr. Setiabudi No. 229, Kota Bandung, Jawa Barat, 40154, Indonesia \\ Corresponding E-mail: anwarsanusi@upi.edu
}

\begin{abstract}
This study aimed at investigating the problems of Arabic teachers' professional competence in improving the quality of the graduates at MA Al-Musdariyah 2 Cimahi. Phenomenology, scientific approach, and a formal juridical approach were used as the method in this study. This study belonged to a case study. The result of this study showed that the main problems related to the teacher's professional competence in teaching and learning Arabic were an unsuitable academic qualification, the lack of teachers' welfare, teachers' discipline and awareness, tutoring, and training. The implication of this study indicated that teachers' professional competence to improve the quality of the graduates had been implemented. However, the implementation of teachers' professional competence was considered less than optimal. It influenced the quality of the graduates. In other words, the objectives of teaching and learning activities were not achieved. Therefore, in this case, teachers as the most important factor in teaching and learning processes should improve their competences as a manifestation to improve the quality of the graduates.
\end{abstract}

Keywords: $\quad$ teaching problems, professional competence, teaching and learning activities, Arabic

\section{Introduction}

Scholars and researchers agree that the quality of teachers is one of the keys to the students' success in academic. ${ }^{1}$ The reality shows that the teachers mostly concern about how to ensure and improve the students' achievement in learning processes. ${ }^{2}$ Hence, the teachers play the main role in educational development, especially those that are conducted formally in schools.

${ }^{1}$ Robert Vagi, et.al., "Dynamics of Preservice Teacher Quality", Teaching and Teacher Education, Vol. 85, 2019, 13-23.

${ }^{2}$ W. Ye \& W. Law, "Pre-service Teachers' Perceptions of Teacher Morality in China", Teaching and Teacher Education, Vol. 86, 2019, 1-13. 
Nevertheless, any improving efforts made to improve the quality of education will not make a significant contribution if there is no support from professional and qualified teachers. Improving the quality of education must be started by the teachers and ended up with the teachers also. ${ }^{3}$ Abdurrahman et.al. point out that the teachers must be able to carry out teaching and learning processes as well as possible as the effort to improve the education. ${ }^{4}$

The result of the study conducted by Nousiainen et al showed that in the digitalization era, the teachers should be able to integrate technology with pedagogy and develop the active classrooms to promote cooperative interaction. ${ }^{5}$ Moreover, the teachers should have professional standards by mastering the materials and teaching strategies, which an encourage the students to study hard.

It is in line with the regulation of Indonesian number 14, 2005 article 2 paragraph 1 concerning teachers and lecturers. It states that teachers have a position as professional personnel at the level of primary, secondary, and early childhood education in the formal education regulated by the statutory regulations. ${ }^{6}$ In article 4 , it explains the teachers as professional personnel as mentioned in article 3 serving for enhancing dignity and the role of teachers as learning agents serving to improve the quality of national education.

Sauri states that professional teachers are the teachers who have the ability and special skills in teacher training so that they are able to carry out their duties and their role as teachers whose maximum ability. ${ }^{8}$ Teachers as professional personnel play a role in implementing the national education system and carrying out the goals of national education namely; developing the students' potency to be people whose faith and who are devoted to God the Almighty, noble, healthy, knowledgeable, capable, creative, independent as well as being democratic and responsible citizens.'

Novauli emphasizes that professional teachers have to have competencies in implementing learning programs. Thus, teachers' competency is one of influencing factors to achieve teaching and learning objectives. ${ }^{10} \mathrm{~A}$ teacher is called the competent 2009), 5 .

${ }^{3}$ E. Mulyasa, Standar Kompetensi dan Sertifikasi Guru, Cet. IV, (Bandung: Remaja Rosdakarya,

${ }^{4}$ Maman Abdurrahman, et.al., "Tantangan Guru Bahasa Arab Madrasah Aliyah dalam Perspektif Kompetensi Pedagogik dan Profesional”, Arabiyat: Jurnal Pendidikan Babasa Arab dan Kebahasaaraban, Vol. 2, No. 1, 2015, 44-58.

5 Nousiainen, et.al., "Teacher Competencies in Game-based Pedagogy", Teaching and Teacher Education, Vol. 74, 2018, 85-97.

6 Hamid Darmadi, "Tugas, Peran, Kompetensi, dan Tanggung Jawab Menjadi Guru Profesional”, Jurnal Edukasi, Vol. 13, No. 2, 2015, 161-174.

7 Departemen Pendidikan Nasional, Peraturan Pemerintah Nomor 19 Tabun 2005 tentang Standar Nasional Pendidikan, (Jakarta: Depdiknas, 2007).

8 Sofyan Sauri, Membangun Profesionalisme Guru Berbasis Nilai Bahasa Santun, Bagi Pembinaan Kepribadian Bangsa yang Bijak, (Bandung: UPI, 2009), 1.

${ }^{9}$ Munirah, "Sistem Pendidikan di Indonesia: antara keinginan dan realita", Auladuna, Vol. 2, No. 2, 2015, 233-245.

${ }^{10}$ M Feralys Novauli, "Kompetensi Guru dalam Peningkatan Prestasi Belajar pada SMP Negeri dalam Kota Banda Aceh", Jurnal Administrasi Pendidikan, Vol. 3, No. 1, 2015, 45-67. 
one if he/she has the ability in terms of knowledge, skill, and attitude. Boyatzis adds that "a competency is defined as capability or ability" meaning as the ability and skill." Daharti et al point out that competency is also defined as knowledge of skill and basic values reflected in habits of thinking and acting. ${ }^{12}$ It is emphasized by Herppich et al who states that competency could be understood as the relevant thinking ability for mastering the real life. ${ }^{13}$ It is in accordance with what Sagala states that "competency is a combination of knowledge (thinking power), attitude (heart power), and skills (physical power) that are manifested in the form of deeds". ${ }^{14}$

Based on the above statements, teachers' competencies could be defined as a unanimity of knowledge, skills and attitudes reflected in the form of intelligent and responsible behaviors possessed by a teacher in carrying out their duties. Moreover, a teacher plays not only as someone who influences the others' behaviors but also as someone who is able to conveys values, norms, and so forth to the students and the community.

In other words, according to Usman, there are three duties of being a teacher namely; educating, teaching and training. Educating means continuing and developing life values. Then, teaching means continuing and developing knowledge and training means developing students' skill to survive. ${ }^{15}$ In order to carry out the duties and responsibilities, Suyanto and Djihad point out that a teacher is required to have certain abilities and competencies as part of teachers' professionalism. The teachers have to have teaching authority based on their qualifications as educators. Each teacher should have professional abilities in the field of teaching and learning. ${ }^{16}$

Thus, the success of teachers in carrying out their duties, either as murabbi, or as the agent of change in society is greatly influenced by their qualification and competencies. There is no possibility for those who do not have such a qualification and a competence can be a successful teacher.

Based on Islamic perspective, every single job must be done professionally. Being a teacher must work professionally along with the competencies she/ he has already possessed so that he/she works based on his/her ability. The teachers should work professionally and could carry out their job as well as possible. It is in line with QS. Al-Zumar verse 39:

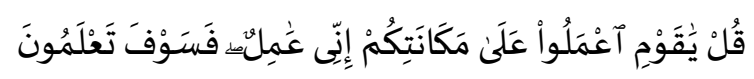

11 R. E. Boyatzis, "Competency in the $21^{\text {st }}$ Century", International Journal of Management Development, Vol. 27, No. 1, 2008, 5-12.

12 Daharti, et.al., "Strategi Peningkatan Kompetensi Guru dengan Pendekatan Analysis Hierarchy Process", JEJAK journal of economic and Policy, Vol. 6, No. 1, 2013, 81-92.

13 Stephanie Herppich, “Teachers' assessment competence: Integrating knowledge-, process-, and product-oriented approaches into a competence-oriented conceptual model", Teaching and Teacher education, Vol. 76, 2018, 1-13.

${ }^{14}$ S. Sagala, Kemampuan Profesional Guru dan Tenaga Kependidikan, (Bandung: Alfabeta, 2009), 23.

${ }^{15}$ M Uzer Usman, Menjadi Guru Profesional, (Bandung: PT Remaja Rosdakarya, 2016), 7.

${ }^{16}$ Suyanto \& A. Djihad, Bagaimana Menjadi Calon Guru dan Guru Profesional, Cet II, (Yogyakarta: Multi Pressindo, 2013), 3-4. 
Arabiyât Jurnal Pendidikan Bahasa Arab dan Kebahasaaraban, 7 (1), 2020

"Say, O My people! Work according to your way, I am working (according to My way), then you will come to know"

The interpretation of above verse explains that 'say to them: Hi! My people that are relatives, tribes, and people who live in a society, do a work meaning that do it (what you want) continuously according to your way, abilities and attitudes taught by God, then you will find out it later'. ${ }^{17}$ It is in accordance with a splinter of hadith from our prophet, Muhammad pbuh. that is;

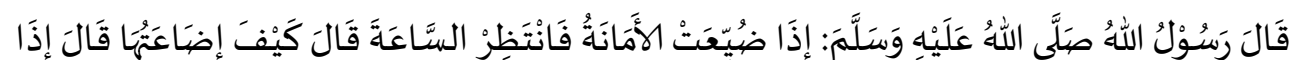

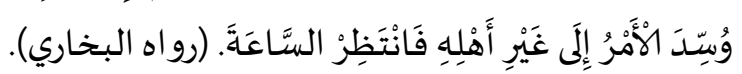

"If all stuff are handled by those who are not an expert, then it will wait for the occurrence of judgment day" (H.R. al-Bukhari). ${ }^{18}$

Based on the above sacred statements, teachers who teach the subject that is not their field and qualification will cause the less optimum results It is because they do not have sufficient abilities, qualifications and skills related to the subject they teach in the classroom.

Therefore, the teacher professionalism needed to develop by the Educational Personnel Educational Institution (LPTK) is a teacher who has pedagogical competencies, personality competencies, social competencies, and professional competencies. Thus, an Arabic teacher must be an agent of change in Arabic teaching and learning. In order to carry out their duties properly, Arabic teachers require to have certain qualifications, including professional competence.

In line with the preceding statements, Arabic teachers must have qualifications (the standard of national education number 19 of 2005) ${ }^{19}$ and professional competencies including; mastering the materials, mastering the standard and core competency, developing creative and innovative teaching and learning materials, developing professionalism continuously through reflecting, and mastering information and technology communication in teaching and learning processes. In other words, a teacher related to his/her professional competency must have rich experience associated with his/her field.

One of the professional competencies frequently required by teachers is the ability to master teaching materials comprehensively and deeply and the ability to choose teaching methods and the presentation of materials to develop teaching and learning processes. The teaching methods used and the ability mastering teaching materials need to be mastered by the teachers because of mutual support. There is no term that mastering teaching methods are more important than mastering teaching

17 M. Quraish Shihab, Tafsir al-Mishbah: Pesan, Kesan dan Keserasian Al-Qur'an, V. 12, (Jakarta: Lentera Hati, 2002), 234.

18 Abdullah Muhammad bin Ismail al-Bukhari, Shabih al-Bukhari, Cet.1. (Riyadh: Dar 'Alimi alKutub, 1996), 21.

${ }^{19}$ Depdiknas, Permendiknas No.16 Tahun 2007 tentang Standar Kualifikasi Akademik dan Kompetensi Guru, (Jakarta: Seketariat Negara, 2007). 
materials or vice versa. If the teachers only master teaching methods without mastering the teaching materials, they will do such a meaningless activity so that the students learn nothing. ${ }^{20}$

In accordance with the above statements, Masnawi and Susiawati, in their study, point out that the concept of teacher's professional competence can be defined as the basic ability to carry out teacher' duties that can be seen from their ability in planning to teach and learning programs, carrying out and managing teaching and learning processes, and assessing teaching and learning processes. ${ }^{21}$ Furthermore, the result of a study conducted by Kasmanti shows that professional competence is as a manifestation of teachers' professionalism that plays an important role in promoting students' learning motivation. ${ }^{22}$ It is supported by the result of a study conducted by Herlianto et al showing that teachers' professional competence has a positive effect on the students' achievements meaning that the higher professional competence possessed by teachers, the higher students' achievement will become. ${ }^{23}$

Thus, the success of a teacher is not only seen from the completion of teaching and learning activities in the classroom but also determined by how far those teaching and learning processes succeed in actualizing the determined basic competence. Moreover, the important factor determining the success of teaching and learning processes is students' learning motivation.

It is undeniable that the quality of students/graduates learning outcomes is seen as an indicator of the success of teachers' professional competence in conducting teaching and learning processes. The indicator to know how the teacher's professional competence in improving student learning outcomes / the quality of the graduates is creating smart, kind-hearted, and skillful graduates. Therefore, this study focuses on investigating the problems of teachers' professional competence in improving the quality of the graduates through Arabic learning. To this end, this study aims to enhance the teachers' professional competence in teaching the Arabic language for non-native speakers. Because of this reason, the researchers are interested to conduct research under the issue and purposively choose Arabic teachers in MA-AlMusdariyah 2 Cimahi as the object of the study. Thus, MA Al-Musdariyah 2 Cimahi was set as the setting of the study.

${ }^{20}$ Sumiati \& Asra, Metode Pembelajaran, (Bandung: CV. Wacana Prima, 2007), 241.

${ }^{21}$ Maswani \& Wati Susiawati, "Kompetensi Profesional Guru Bahasa Arab Madrasah Aliyah Negeri (MAN) di Jakarta", Arabiyat: Jurnal Pendidikan Babasa Arab dan Kebahasaaraban, Vol. 4, No. 2, 2017, 185-203.

${ }^{22}$ Kasmawati, "Pengaruh Guru Profesional terhadap Motivasi Belajar Peserta Didik Pada SMPN 1 Bontoramba Kabupaten Jeneponto", Auladuna, Vol. 2, No. 1, 2015, 42-64.

23 Herlianto, et.al., "Pengaruh Kompetensi Profesional Guru dan Motivasi Belajar Siswa Terhadap Prestasi Belajar Siswa pada Mata Pelajaran Kearsipan SMK Administrasi Perkantoran di SMK Negeri 1 Ciamis", Manajerial, Vol. 3, No. 4, 2018, 70-82. 


\section{Method}

This study applied descriptive qualitative. Bogdan and Taylor (as cited in Moleong, 2005) define qualitative research as research producing qualitative data in the form of written or oral words from people and behaviors observed. ${ }^{24}$ The approaches used in this study are phenomenology, scientific approach and formal juridical approach. Data sources in this study are classified into two namely primary and secondary data sources. Primary data source is data collected directly by the researchers related to the teacher's professional competence to improve the quality of the graduates through learning Arabic in MA Al-Musdariyah 2 Cimahi. These data were obtained by the researchers from several informants that are Arabic teachers and the students of MA Al-Musdariyah $\left(1^{\text {st }}, 2^{\text {nd }}\right.$, and $3^{\text {rd }}$ grade).

Secondary data source is indirect source of data in which the data taken indirectly form the informants or additional data used when it is needed including relevant data taken from Arabic teacher who met the standard of qualification, data about the result of students' learning, documents, and reports and other supporting data.

Data collection techniques used in this study were 1) observations, 2) literature study, 3) interview and 4) documentation. Further, data analysis applied in this study was carried out through three stages namely reducing data, presenting data and drawing conclusions. First stage was reducing the collected data that was a process of selecting, focusing on simplifying the raw data obtained in the research site. This activity carried out on an ongoing basis, namely the reduction of data regarding teachers" professional competence to improve the quality of the graduates through Arabic learning at MA Al-Musdariyah 2 Cimahi.

The second stage was presenting the data. It meant presenting the data that has been filtered and organized as a whole in the form of descriptive narrative. In the data presentation, the data were interpreted from the data found, so that the conclusions were formulated to be more objective.

The third stage was drawing conclusion. In this stage, the researchers drawn conclusions after conducting reducing and presenting the data inductively to answer the research problems. Those three data analysis activities are interrelated in the process of drawing conclusion at the end of the research.

In conducting a research, every data found must be checked for the sake of validity issue so that the truth of research results can be justified and their validity can be proven. The technique used to check the validity of the data in this research is triangulation covering method triangulation, data source triangulation, and theoretical triangulation.

${ }^{24}$ Lexy J. Moleong, Metode Penelitian Kualitatif, (Bandung; PT Remaja Rosdakarya, 2005). 


\section{Result and Discussion}

Increasing professionalism is very closely related to the existence of a professional teacher. However, in an effort to become a professional teacher, teachers must also have teachers' competencies including professional competence.

In the concept of Islamic education, professional competence is a teachers' ability in carrying out their duties based on Islamic concept. ${ }^{25}$ Professional competence is the most core competency must be possessed by all teachers including Arabic teachers.

In the implementation of professional competence, this competence requires the ability of a teacher in planning, conducting, and evaluating the teaching and learning processes. In addition, the teachers should master the materials comprehensively and in depth including mastering the materials related to the content, teaching method, and professional development based on their ability and qualification they already had. Thus, teachers' competence especially professional competence is to be fundamental issue that continuously must be improved by realizing that the success of education is not only determined by the teachers but also various parties involved.

Based on interviews, observations, and documentation, the researchers found several problems related to teachers' professional competence in Arabic teaching and learning at MA Al-Musdariyah 2 Cimahi. Therefore, in this current study, the researches focused on problems encountered by Arabic teachers in planning, conducting, and evaluating teaching and learning processes as a manifestation to achieve better teachers' professional competence.

The conceptual framework flow of the teachers' professional competence to improve the quality of the graduates in teaching and learning Arabic language is illustrated in Figure 1 below.

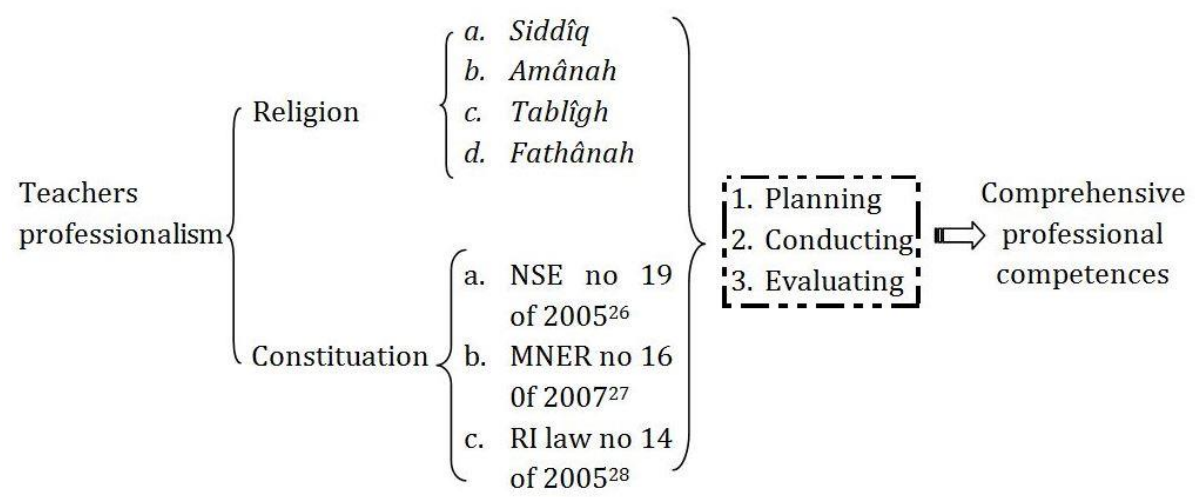

Figure 1. The Flow of the Conceptual Framework

${ }^{25}$ Ngainun Naim, Menjadi Guru Inspiratif. Cet. IV. (Yogyakarta: Pustaka Pelajar, 2013), 61.

${ }^{26}$ National Standards of Education No. 19 of 2005.

27 Ministry of National Education Regulation No. 16 of 2007 about teachers' standard competency.

${ }^{28}$ RI Law No. 14 of 2005 concerning Teachers and Lecturer. 
As illustrated in Figure 1, a teacher must have a strong foundation in teaching. In teaching, a teacher should be oriented on two aspects, namely religious and legal aspects. Besides, a teacher must learn and emulate the characteristics, and prophetic values imaged in the Prophet Muhammad pbuh.; siddiq, amanah, tabligh, fatannah. The Prophet Muhammad pbuh. is a perfect teacher and a good role model for humanity. In a Mondial era like today, following what had been taught by the Prophet Muhammad pbuh. is necessary. Thus, an Arabic Language teacher will be able to achieve learning goals and have excellent professional competence when he/she makes the prophet Muhammad pbuh. As the leading figure in teaching.

\section{The Problems of Arabic Teachers in Planning Arabic Teaching and Learning Activities}

Before conducting teaching and learning activities, a teacher should make any plan related to teaching and learning activities that are going to be done. Sanjaya said that making lesson plan is the process of decision making as the results thinking rationally about specific learning goals and objectives, i.e. the change of behavior and a series of activities that must be carried out as an effort to achieve the goal and objective by utilizing all the available potential and learning resources. ${ }^{29}$ The final result of decision making is organized documents containing those issues so that those documents can be used as the reference and the guidelines to conduct teaching and learning activities.

Rusydie later adds that being a professional teacher who has skill and ability to educate should have and understand the goals and objectives of education. By comprehending those goals and objectives of education fully, a teacher could make a priority scale and work on the right track. It means the responsibility of Arabic teachers is to develop Arabic teaching and learning curriculum. ${ }^{30}$ In other words, teachers are required to look for new concepts, perfecting educational practices especially in teaching and learning Arabic. It is in line with what Mudlofir states that a curriculum is a plan or a program of a teaching implementation. ${ }^{31}$

Teaching planning was organized in the form of syllabus or lesson plan (RPP) based on content standards. Planning teaching and learning covers organizing lesson plan, preparing media, learning source and assessment and evaluation tool, and teaching scenario. The organizing of syllabus and RPP adjusted to the teaching approach used. ${ }^{32}$

Hence, in order to achieve the objective of Arabic teaching and learning processes, teachers should be able to plan teaching and learning activities properly and relevant with the existing regulation theory. In fact, teachers planning Arabic teaching and learning activities can be separated from 1) goals and objectives 2) Arabic teaching

${ }^{29}$ Wina Sanjaya, Perencanaan dan Desain Sistem Pembelajaran, (Jakarta: Kencana, 2015), 28-29.

${ }^{30}$ Salman Rusydie, Tuntunan Menjadi Guru Favorit, Cet. I. (Jakarta: Flash Book, 2012), 14.

31 Ali Mudlofir, Pendidik Profesional: Konsep, Strategi, dan Apllikasinya dalam Peningkatan Mutu Pendidikan di Indonesia, Cet. I. (Jakarta: Raja Grafindo Persada, 2012), 64.

32 Peraturan Menteri Pendidikan dan Kebudayaan Nomor 22 Tahun 2016. 
and learning curriculum, 3) syllabus, 4) RPP, 4) textbooks used by the Arabic teachers. From those five elements of planning Arabic teaching and learning activities, based on the result of the interviews, observations, and documentations, researchers found that problem related to making lesson plan was Arabic teachers rarely made lesson plan for every meeting. There are several factors that cause it occurs including; 1) the school condition that does not support in terms of facilities 2) Arabic teachers already have children who are still toddlers so that making lesson plans everyday seems difficult because they have to teach and take care of the family, and 3) Arabic teachers do not teach just at one institution.

Those problems become the problems of the educational stakeholder in improving the quality of the graduates. A teacher is considered mastering teaching materials well when he/she makes preparation before. The indicator identifying the teachers has made preparations before is making lesson plan, syllabi, and so forth actualized in leaning units.

Thus, teaching materials mastery is important in teaching process in order to achieve the goals and objectives of teaching and learning activities. In making lesson plan, teachers should know the meaning and the purpose of lesson plan they made and master the elements involved either theoretically or practically. Therefore, the ability to plan teaching and learning programs is the estuary of all theoretical knowledge, basic skills, and deep understanding of learning objects and teaching situations.

\section{The Problems of Arabic Teachers in Conducting Arabic Teaching and Learning Activities}

In conducting Arabic teaching and learning, the teachers are closely related to professional competence they have. It is in line with the content of the Ministerial Regulation of National Education No 16 of 2007 covering: 1) mastering the materials, 2) developing the materials they teach creatively, 3) mastering standard and basic competency of the subject they master, 4) developing sustainable professionalism by taking reflective actions, and 5) making use of information and communication technology to communicate and self-development.

a) The teacher in mastering the materials being taught

Professional teachers should master the scientific structures and methods. Structures here can be defined as a general pattern of teaching and learning. Mastering the scientific structures methods has the implication that the teacher must master the steps of teaching and learning activities for deepening knowledge or mastering the materials being taught. Based on the results of the interview with an Arabic teacher, he said that,

"A teacher must master the materials they are going to deliver. I teach Arabic so I prepare and master the materials related to Arabic before. I prepare a suitable teaching method because each student has different perceived ability regarding the materials given. There are students who can understand the delivered materials quickly and there are students who understand the delivered materials slowly. Moreover, there 
are several students who have not understood how to read Arabic letters. Consequently, the students are difficult to learn Arabic. In addition, Arabic teachers state that the last educational background is not from Arabic education/literature department but Islamic law department at UIN Sunan Gunung Jati Bandung. However, Arabic teachers used to learn Arabic at Imarat for six semesters and six months in Saudi Arabia."

Based on the statement above, that Arabic teachers in Madrasah Aliyah of Cimahi have not met the standard of qualification. In line with the previous statement, according to the Ministry of Education and Culture (Kemendikbud) quoted by Masoka et al, teachers' qualifications that are under qualification and less competent, as well as mismatch between educational qualifications and the field mastered, are also as an inducing factor of the low of educational quality. ${ }^{33}$ Hence, Arabic teachers have to have relevant qualifications with the subject they master in order to create qualified education and maximize learning outcomes.

Other than that, the explanation above illustrates that mastering teaching materials is as an integral part of teaching and learning processes. Teachers' mastery of teaching materials greatly influences on students learning outcomes. Learning process and students' results depend on how well teachers master the teaching materials and their teaching skills and ability. It means the higher teachers' mastery of teaching materials, the higher the students' result will become and vice versa.

Although the Arabic teachers have not met the standard qualification, the researchers found that they, in terms of mastering the Arabic materials, are good. It could be seen through three aspects used by the researchers as the guidelines in conducting observations.

\section{Phonological aspect}

In this aspect, Arabic teachers at MA Al-Musdariyah articulated hiwar materials about التسهيلات العامة والاجتماعية with good pronunciation (makhärij al-hurûf) appropriate with the characteristics of each letter.

\section{Grammatical aspect}

The Arabic teachers gave the grammatical examples of the number of filiyah covering fi'il mâdhî, fa'il, and maf' $\hat{u} l$ that did not focus only on an example but also on those on textbook even though there are several examples taken from textbooks.

\section{The aspect of Arabic vocabulary mastery}

The Arabic teachers explained the materials and gave examples related to the sentences in Arabic variously. It indicated that teachers' Arabic vocabulary mastery in Arabic teaching was good.

${ }_{33}$ M Masoka, et.al., "Studi Eksplorasi Kualifikasi dan Kompetensi Guru Bidang Studi Biologi SMP-SMA Sebagai Basis Program Peningkatan Kualitas Pendidikan”, Jurnal Pendidikan, Vol. 2, No. 4, 2017, 516-523. 
Apart from those above three aspects, the researchers added a supervision instrument of teaching and learning process (process standard) from the principal as the reference to know the quality of teaching conducted by Arabic teachers especially to know the level of teachers' materials mastery. The supervision instrument of teaching and learning process was depicted as follows;

Table 1. The principal's supervision instrument of teaching and learning process

\begin{tabular}{|c|c|c|c|c|c|c|}
\hline \multirow{2}{*}{ No } & \multirow{2}{*}{ The observed aspects } & \multicolumn{4}{|c|}{ Yes } & \multirow[t]{2}{*}{ No } \\
\hline & & 4 & 3 & 2 & 1 & \\
\hline 1 & Lesson plan (RPP) & & & $\checkmark$ & & \\
\hline 2 & Timely attendance & & $\checkmark$ & & & \\
\hline 3 & $\begin{array}{l}\text { Clarification of basic competencies that must be } \\
\text { achieved by students }\end{array}$ & $\checkmark$ & & & & \\
\hline 4 & Clarity of the assessment system used & $\checkmark$ & & & & \\
\hline 5 & Clarity of learning objectives & $\checkmark$ & & & & \\
\hline 6 & Motivating the students to learn & $\checkmark$ & & & & \\
\hline 7 & Readiness of learning tools and media & & & $\checkmark$ & & \\
\hline 8 & Readiness of teaching materials & $\checkmark$ & & & & \\
\hline 9 & $\begin{array}{l}\text { Involving the students in searching extensive and } \\
\text { in-depth information from various sources }\end{array}$ & & $\checkmark$ & & & \\
\hline 10 & $\begin{array}{l}\text { Using various teaching approach, media, and } \\
\text { other learning resources }\end{array}$ & & $\checkmark$ & & & \\
\hline 11 & $\begin{array}{l}\text { Facilitating interaction between the students, the } \\
\text { teachers, learners-environment, and other } \\
\text { learning resources }\end{array}$ & & $\checkmark$ & & & \\
\hline 12 & $\begin{array}{l}\text { Actively involving the students } \\
\text { in every learning activity }\end{array}$ & $\checkmark$ & & & & \\
\hline 13 & $\begin{array}{l}\text { Facilitating students to make } \\
\text { experiments in the laboratory, studio or field }\end{array}$ & & & & $\checkmark$ & \\
\hline
\end{tabular}

Table 1 above shows that the level of teachers' materials mastery has score of four. It means the Arabic teachers show a good mastery. In addition, the achievement of students" outcomes is not optimal. It might be influenced by teachers' discipline. The results taken from the observations showed that the level of Arabic teachers' discipline in MA Al-Musdariyah 2 Cimahi was low. It was caused by the teachers who were late for class, those who got out quickly and just gave assignments and homework for students, and those who were absent because of having certain business. Those gave impact to students. It is in accordance with what a student stated during the interview, he said that,

"Sometimes, the teachers come late or they are absent for certain moment without notification and there is no teacher who replaces them so that we do not learn and several students go around outside the classroom during learning time".

The above student' statement shows that discipline is an important matter applied in everyday life, especially for teachers. The teachers who should be an example because of their knowledge and be a role model because of their good behavior should carry out their duties properly and earnestly by getting used to come on time, leaving their works related to personal issue for the sake of carrying out their duties as a teacher. 


\section{b) Developing teaching and learning materials creatively}

In terms of teaching and learning materials developments, Arabic teachers of MA Al-Musdariyah 2 Cimahi were doing well enough. They developed the materials creatively. They chose the materials based on the level of students' development because each student has different level of development and Intelligence Quotient (IQ).

It was done in order to make the students more easily understand the materials given. The teachers conveyed the materials determined based on the level of the students' ability and IQ. They also delivered the materials simply and easily understood by the students. Further, in developing the materials creatively, the teachers always used methods adjusted based on the level of students' ability in order to create fun and interesting learning environment so that the students did not get bored easily. Likewise, teachers always used different media based on the materials that were going to deliver and students' ability.

Based on table 1, the use of media and school facilities got scores 2. It means that the Arabic teachers are skillful enough in utilizing the provided media and facilities. The school has not provided compete facilities such as; unavailable Arabic language laboratory, and adequate Arabic dictionaries. Then, as the solution of those problems, Arabic teachers used an alternative way by conducting programs outside the class hours including reading and writing Qur'an (BTQ), rememorizing Arabic vocabularies at certain time such as before starting the lesson or between break time.

\section{c) Mastering the standard and basic competencies of the subject}

A competent teacher must comprehend standard competency of the subject he teaches, basic competency, and the objectives of teaching and learning activities. It means the Arabic teachers should comprehend the standard and basic competency of Arabic teaching and learning. Comprehending standard competency, either basic or core, is the mainly issue before conducting teaching and learning processes. Administrative preparations made by teachers include making syllabus or lesson plan (RPP) and mastering lesson plan they has made. Hence, the objectives of teaching and learning activities is to be the main priority in teaching and learning activities.

However, the fact showed that the teachers rarely make lesson plan and convey the objectives of teaching and learning activities that must be achieved by the students before starting the class and the benefits that are going to get. Consequently, the students do not know the objectives and what benefits they are going to get from the materials given.

\section{d) Developing the sustainable professionalism through reflective actions}

Based on the results of the interview, Arabic teachers were good enough in developing the sustainable professionalism. The Arabic teachers made self-reflection toward their performances by evaluating the outcomes of teaching and learning activities seen from the students' score and the results of assessment using the principal' supervision instrument. It was done to know what the shortcomings were and the issues that have to improve regarding teachers' performance. In addition, self- 
evaluation was made to know whether teaching and learning processes conducted have achieved the objectives of teaching and learning process.

Moreover, Arabic teachers develop their sustainable professionalism by reading books frequently. However, they rarely join any educational seminars, trainings, Workshop activities, MGMP (Teacher's Deliberation Subjects), KKG (Teacher Working Group), educational training guided by principal, the head of Foundations and Government Offices who concern with teachers' professional competence.

Further, based on the results of the interviews, it was found that the school did not support financially the improving of teachers' professionalism through trainings as mentioned before. It was so sad knowing that the teachers' salary was also too small. Yet, according to Asmarani who states that there are two influencing factors regarding professional competence namely; 1) internal factors including teachers' educational background, teaching experience, teachers' welfare and health, 2) external factors covering educational facilities, the application of discipline in schools and principal supervision. ${ }^{34}$ Thus, teachers' welfare is the most fundamental thing that should be considered regarding improving teachers' professional competence.

e) Utilizing information and communication technology to communicate and self-development

Arabic teachers always utilize information and communication technology. They use smartphone and laptop to support them. They learn from various sources to improve their knowledge including utilizing either the available internet access provided by the school or their private internet access. Thus, the Arabic teachers at MA Al-Musdariyah 2 Cimahi have utilized information and communication technology to develop themselves in improving their knowledge.

\section{The Problems of Arabic Teachers in Evaluating Arabic Language Learning}

Evaluation is the most important part of teaching and learning activities conducted by the teachers to know the level of students' knowledge and ability and teaching programs. Evaluation can be done at the beginning of the lesson to find out how far the level of the students' knowledge and it can be done in the form of final exam at the end of the lesson to know the level of the students' perceived ability related to the materials given. Evaluation is also useful to know the changes in terms of the students' knowledge, skills and attitudes in a learning unit or in a learning program that has been carried out. Therefore, being a teacher is required to be able to evaluate the teaching and learning activities conducted. The following is the result of the interview regarding the model of evaluation done by Arabic teacher. An Arabic teacher said that,

The form of assessment that I do is assessment in the form of oral questions (before starting the lesson, the teachers give questions orally to the students in the

${ }^{34}$ Nur'aeni Asmarani, "Peningkatan Kompetensi Profesional Guru di Sekolah Dasar", Jurnal Administrasi Pendidikan, Vol. 2, No. 1, 2014, 503-510. 
form of an understanding or the materials given. Then, it is continued by conducted by conducting the lesson), assessment in the form of assignments, assessment in the form of daily and semester tests. Then, viewed form the aspects of competition among schools, the students seem lost especially related to the Arabic issues.

The assessment of the evaluation carried out not only rely on cognitive domain related to the subjects that are usually done after explaining a chapter and at the end of semester but also on affective (attitude) and psychomotor assessment. After knowing the results of the evaluation, the next step taken is follow-up actions for the students whose good grades and who have achieved the standard competency are given materials enrichment program. Whilst, the students who have lower score are given remedial program by repeating the materials that has been taught until they really understand and then taking a test again.

The findings of this study showed that Arabic teachers at MA Al-Musdariyah 2 Cimahi are able to carry out the assessment or evaluation, either evaluation in the form of formative test meaning that the evaluation is conducted after each teacher completed one chapter, after at the end of the explanation or evaluation at the end of the semester. Manifestation of learning outcomes is the change of behavior. Teaching and learning activities can be said to be efficient if they give maximum learning outcomes and produce qualified graduates.

\section{Conclusion}

Based on the analysis and the discussion, it shows that the professional competence of the Arabic language teacher in Madrasah Aliyah Al-Musdariah 2 Cimahi was considered less than optimal. This is indicated by the teachers' lack of making lesson plans at each learning meeting and the lack of discipline for some teachers at MA Al-Musdariyah 2 Cimahi, which needs to be improved. The inadequate behavior was observed from the lack of the presence and compliance of the rules of teaching the Arabic language. Besides, the teacher's less optimality behavior occurs due to the teacher's lack of implementing the discipline in carrying out their duties as teachers, usually late to attend classes and dismiss classes before a particular time. Instead, they only gave assignments or homework. Furthermore, the inadequate occurs due to the unsuitable qualified teachers and the shortage of facilities and infrastructure. For example, the teachers' small wage salary, the lack of guidance, training, and technology are among the deficiencies that cause a lack of professional competence and hence affect the performance of teachers in carrying out their duties as professional teachers.

Several solutions can be done to improve the teacher's professionalism aimed to improve learning outcomes or the quality of graduates in MA Al-Musdariyah 2 Cimahi. The solutions the researchers offer after analyzing a number of inhibiting factors in achieving students' learning outcomes as follows. First, the teacher must be religion-oriented in order to be a professional teacher with responsibility for all his duties. Second, the teacher should improve their discipline in which they should be a good role model for their students. Third, the school should complete all facilities and 
infrastructure for supporting active teaching and learning activities. Fourth, directing the teachers to join more sustainable coaching and giving the opportunities for teachers to pursue the higher education level in linear level accordingly with the subjects they teach. Fifth, making rules or systems for each teacher who teach at MA Al-Musdariyah 2 Cimahi in order to not teach at another school in which the teacher's welfare is met. To this end, teachers must develop their professional competence continuously for the sake of producing qualified graduates.]

\section{REFERENCES}

Abdurrahman, Maman., et.al. "Tantangan Guru Bahasa Arab Madrasah Aliyah dalam Perspektif Kompetensi Pedagogik dan Profesional", Arabiyat: Jurnal Pendidikan Babasa Arab dan Kebahasaaraban, Vol. 2, No. 1, 2015.

Asmarani, Nur'aeni. "Peningkatan Kompetensi Profesional Guru di Sekolah Dasar", Jurnal Administrasi Pendidikan, Vol. 2, No. 1, 2014.

Boyatzis, R. E. "Competency in the $21^{\text {st }}$ Century", International Journal of Management Development, Vol. 27, No. 1, 2008.

al-Bukhari, Abdullah Muhammad bin Ismail. Shahih al-Bukhari, Cet. 1. Riyadh: Dar 'Alimi al-kutub, 1996.

Daharti., et.al. "Strategi Peningkatan Kompetensi Guru dengan Pendekatan Analysis Hierarchy Process", JEJAK journal of economic and Policy, Vol. 6, No. 1, 2013.

Darmadi, Hamid. "Tugas, Peran, Kompetensi, dan Tanggung Jawab Menjadi Guru Profesional", Jurnal Edukasi, Vol. 13, No. 2, 2015.

Herlianto., et.al. "Pengaruh Kompetensi Profesional Guru dan Motivasi Belajar Siswa Terhadap Prestasi Belajar Siswa pada Mata Pelajaran Kearsipan SMK Administrasi Perkantoran di SMK Negeri 1 Ciamis", Manajerial, Vol. 3, No. 4, 2018.

Herppich, Stephanie. 'Teachers' assessment competence: Integrating knowledge-, process-, and product-oriented approaches into a competence-oriented conceptual model", Teaching and Teacher education, Vol. 76, 2018.

Kasmawati. "Pengaruh Guru Profesional Terhadap Motivasi Belajar Peserta Didik Pada SMPN 1 Bontoramba Kabupaten Jeneponto", Auladuna, Vol. 2, No. 1, 2015.

Masoka, M., et.al. "Studi Eksplorasi Kualifikasi dan Kompetensi Guru Bidang Studi Biologi SMP-SMA Sebagai Basis Program Peningkatan Kualitas Pendidikan", Jurnal Pendidikan, Vol. 2, No. 4, 2017.

Maswani., \& Wati Susiawati. "Kompetensi Profesional Guru Bahasa Arab Madrasah Aliyah Negeri (MAN) di Jakarta”, Arabiyat: Jurnal Pendidikan Bahasa Arab dan Kebahasaaraban, Vol. 4, No. 2, 2017. 
Arabiyât Jurnal Pendidikan Bahasa Arab dan Kebahasaaraban, 7 (1), 2020

Moleong, Lexy J. Metode Penelitian Kualitatif. Bandung: P'T Remaja Rosdakarya, 2005.

Mudlofir, Ali. Pendidik Profesional: Konsep, Strategi, dan Apllikasinya dalam Peningkatan Mutu Pendidikan di Indonesia, Cet. I. Jakarta: Raja Grafindo Persada, 2012.

Mulyasa, E. Standar Kompetensi dan Sertifikasi Guru, Cet. IV. Bandung: Remaja Rosdakarya: 2009.

Munirah. "Sistem Pendidikan di Indonesia: antara keinginan dan realita", Auladuna, Vol. 2, No. 2, 2015.

Naim, Ngainun. Menjadi Guru Inspiratif, Cet. IV. Yogyakarta: Pustaka Pelajar, 2013.

Nousiainen., et.al. "Teacher Competencies in Game-based Pedagogy", Teaching and Teacher Education, Vol. 74, 2018.

Novauli, M Feralys. "Kompetensi Guru dalam Peningkatan Prestasi Belajar pada SMP Negeri dalam Kota Banda Aceh", Jurnal Administrasi Pendidikan, Vol. 3, No. 1, 2015.

Peraturan Menteri Pendidikan dan Kebudayaan Nomor 22 Tahun 2016.

Peraturan Pemerintah Nomor 19 Tahun 2005 tentang Standar Nasional Pendidikan.

Permendiknas Nomor 16 Tahun 2007 tentang Standar Kualifikasi Akademik dan Kompetensi Guru.

Rusydie, Salman. Tuntunan Menjadi Guru Favorit, Cet. I. Jakarta: Flash Book, 2012.

Sagala. S. Kemampuan Profesional Guru dan Tenaga Kependidikan. Bandung: Alfabeta, 2009.

Sanjaya, Wina. Perencanaan dan Desain Sistem Pembelajaran. Jakarta: Kencana, 2015.

Sauri, Sofyan. Membangun Profesionalisme Guru Berbasis Nilai Bahasa Santun, Bagi Pembinaan Kepribadian Bangsa yang Bijak. Bandung: UPI, 2009.

Shihab, M. Quraish. Tafsir al-Mishbab: Pesan, Kesan dan Keserasian Al-Qur'an, V. 12. Jakarta: Lentera Hati, 2002.

Sumiati \& Asra. Metode Pembelajaran. Bandung: CV. Wacana Prima, 2007.

Suyanto \& A. Djihad. Bagaimana Menjadi Calon Guru dan Guru Profesional, Cet II. Yogyakarta: Multi Pressindo, 2013.

Usman, M Uzer. Menjadi Guru Profesional. Bandung: PT Remaja Rosdakarya, 2016.

Vagi, Robert., et.al. "Dynamics of Preservice Teacher Quality", Teaching and Teacher Education, Vol. 85, 2019.

Ye, W., \& W. Law. "Pre-service Teachers' Perceptions of Teacher Morality in China”, Teaching and Teacher Education, Vol. 86, 2019. 